\title{
MARKETING MIX, BRAND EQUITY, AND PURCHASE DECISIONS OF PACKAGED RICE PRODUCTS
}

\author{
Mochammad Reza Firmansyah"), Ujang Sumarwan ${ }^{* *}$, Muhammad Mukti Ali ${ }^{* * *}$ \\ ${ }^{*}$ School of Business, IPB University \\ Jl. Pajajaran Bogor 16151, Indonesia \\ ${ }^{* *}$ Departement of Consumer and Family, Faculty of Human Ecology, IPB University \\ Jl. Darmaga, Darmaga Campus, Bogor 16682, Indonesia \\ ${ }^{* * *}$ INABA University \\ Jl. Soekarno-Hatta No.448, Bandung 40266, Indonesia
}

\begin{abstract}
In selling packaged rice products, Perum BULOG needs to implement the right marketing strategy in order to increase the buying interest of prospective consumers. This study aims to analyze factors that affect brand equity and purchasing decisions of packaged rice products. The research design uses a descriptive approach through surveys by disseminating questionnaires online. The research was conducted in September-October 2020 on 270 rice consumers in DKI Jakarta and Bodetabek who were selected using nonprobability sampling method through convenience sampling technique. The variables studied in this study were product, price, place, promotion, brand equity, and purchasing decisions. Data analysis method using SEM analysis with Lisrel 8.80 software. The results showed that product, price, place, and promotion had a significant positive influence on brand equity and purchasing decisions. The variables that most influence purchasing decisions are product, place, and brand equity. Based on the results of the study, it can be concluded that product, place, and brand equity are factors that should be a top priority for manufacturers to make improvements and development. In addition, rice products sold using brands and packaging are more attractive to consumers than rice products sold without brands and packaging. In this regard, in addition to the marketing mix strategy, manufacturers must implement brand and packaging strategies well to improve consumer purchasing decisions on their rice products.
\end{abstract}

Keywords: brand equity, marketing mix, packaged rice products, purchase decisions, SEM

\begin{abstract}
Abstrak: Dalam menjual produk beras kemasan, Perum BULOG perlu menerapkan strategi pemasaran yang tepat agar dapat meningkatkan minat beli calon konsumen. Penelitian ini bertujuan untuk menganalisis faktor-faktor yang memengaruhi ekuitas merek dan keputusan pembelian produk beras kemasan. Desain penelitian menggunakan pendekatan deskriptif melalui survei dengan menyebarkan kuesioner secara online. Penelitian dilakukan pada bulan September-Oktober 2020 terhadap 270 orang konsumen beras di wilayah DKI Jakarta dan Bodetabek yang dipilih menggunakan metode non-probability sampling melalui teknik convenience sampling. Variabel yang diteliti dalam penelitian ini adalah produk, harga, lokasi, promosi, ekuitas merek, dan keputusan pembelian. Metode analisis data menggunakan analisis SEM dengan software Lisrel 8.80. Hasil penelitian menunjukkan bahwa produk, harga, lokasi, dan promosi memiliki pengaruh positif yang signifikan terhadap ekuitas merek dan keputusan pembelian. Variabel yang paling berpengaruh terhadap keputusan pembelian adalah produk, lokasi, dan ekuitas merek. Berdasarkan hasil penelitian, dapat disimpulkan bahwa produk, lokasi, dan ekuitas merek adalah faktor yang harus menjadi prioritas utama bagi produsen untuk dilakukan perbaikan dan pengembangan. Selain itu, produk beras yang dijual menggunakan merek dan kemasan lebih menarik bagi konsumen dibandingkan produk beras yang dijual tanpa merek dan kemasan. Sehubungan hal tersebut, disamping strategi bauran pemasaran, produsen harus menerapkan strategi merek dan kemasan dengan baik untuk meningkatkan keputusan pembelian konsumen terhadap produk beras mereka.
\end{abstract}

Kata kunci: bauran pemasaran, ekuitas merek, keputusan pembelian, produk beras kemasan, SEM

${ }^{1}$ Corresponding author:

Email: zenezza@gmail.com 


\section{INTRODUCTION}

Perum BULOG is a state-owned public company engaged in food logistics. With the issuance of Government Regulation No. 7 of 2003, BULOG officially switched status from Non-Departmental Government Institutions (LPND) to state-owned enterprises in the form of Perusahaan Umum (Perum). With the change in status, in addition to carrying out Public Service Obligation (PSO) tasks such as Raskin distribution and management of government rice reserves/Cadangan Beras Pemerintah (CBP), Perum BULOG also conducts business in the commercial sector through three pillars, namely industry, trade, and services.

As a state-owned enterprise, Perum BULOG must have its own income and profit to be able to finance all operational needs of its business. One form of Perum BULOG commercial business is the sale of premium rice. Premium rice has economic value and better quality than medium rice used for Raskin and CBP. In developing premium rice sales, Perum BULOG decided to create premium packaged rice products for the retail market branded "Beras Kita". But in selling its products, Perum BULOG experienced various obstacles and challenges, including stigma in the community who thought that Perum BULOG products, especially rice, have poor quality. To be able to compete with other brands of packaged rice products, Perum BULOG needs to carry out various marketing strategies to introduce and attract consumers to buy "Beras Kita" products.

According to Sutrisno (2007), in line with the increasing income, education, and easy access to public information, rice consumption patterns in Indonesia have changed. Currently, rice consumers consider rice not only as a commodity but as a product with certain criteria. Consumer preference for the attributes of rice products that were previously only seen from the type, comfort and price has increased with other attributes such as brand, packaging, quality, nutritional content, and others. This is especially the case for consumers who have a sufficient level of education/knowledge and economic ability. Today, the consumers will gather information and learn about the brands of rice available in the market before making a purchase decision process. Therefore, in order to increase sales, the right marketing mix strategy and strong brand equity are needed to introduce packaged rice products so that the public can easily know, memorize, and remember the brand of packaged rice products to encourage them to buy the rice products.

The marketing mix is all marketing efforts that aim to inform customers and potential customers about the benefits of a product so that they start buying or continuing the purchase of the product (Adebisi, 2006). McCarthy in Kotler and Keller (2006) grouped the marketing mix into 4 categories namely product, price, place, and promotion. According to Aaker (1997), brand equity is a set of assets and liabilities related to a brand, name, and symbol that can add or decrease the value provided by goods or services to the company or its customers. Brand equity is grouped into brand awareness, brand associations, quality perception, brand loyalty, and other brand assets. Meanwhile, according to Tjiptono (2018), the decision of consumers to make purchase decisions consists of several dimensions, namely product choice, brand choice, dealer choice, time of purchase, number of purchases, and payment method.

Several previous studies related to the marketing mix, brand equity, and purchasing decision have been made by several researchers. The results of Ulfah et al. (2016) research showed that consumers desire to buy and not to buy fruit iced drinks is influenced by the price and physical environment factors. While the results of Aritonang et al. (2015) research showed that of the six variables of the marketing mix, the variable of prices and places have a significant influence on the purchasing decisions of soybean meal raw materials. Research conducted by Marwa et al. (2014) shows that there are at least five factors of the marketing mix that influence life insurance purchasing decisions and the product mix are the variables that most influence life insurance purchasing decisions.

Yoo et al. (2000), conducted research on the relationship between elements of the marketing mix and the creation of brand equity, with the result that price promotions related to low brand equity. Meanwhile, the high cost of advertising, high prices, good store image, and distribution intensity are associated with high brand equity. Another research conducted by Aghaei et al. (2014) shows a positive and meaningful relationship between the marketing mix of services and brand equity. Meanwhile, in a study conducted by Chandra (2015), it was found that the intensity of marketing mix activity did not have a significant effect on brand equity with brand awareness as a mediation variable. 
Research conducted by Nursaman et al. (2014) on the equity of fruit outlet brands based on consumer perception shows that the factors that affect brand equity are brand loyalty and brand awareness. Etriya et al. (2004) conducted a study aimed at analyzing factors that affect the brand equity of cooking oil products, with the results that manufacturers should strengthen the differentiation of cooking oil products on non-preservative attributes and brand image as healthy cooking oil, and to maintain its availability in all outlets. Meanwhile, research conducted by Meiria (2017) showed that brand equity factors, namely brand awareness, brand associations, impressions of quality, and brand loyalty both partially and simultaneously have a significant effect on purchasing decisions. Similarly, the research conducted by Adelina (2016) showed that there is an influence of brand equity on the decision to purchase isotonic drinks.

Another study was conducted by Nugroho et al. (2015) to analyze factors that influence consumers in making decisions on the purchase of organic tofu products, with the result that there are factors that influence consumers in purchasing decision making including age, education, knowledge and external factors of products that are part of the marketing mix such as price, advertising, personal selling and place of sale. Meanwhile, the results of Sumarwan and Noviandi's research (2013) on how consumers make decisions on the purchase of organic rice, showed that the purchasing decision process through the stages of need recognition, information search, alternative evaluation, purchase, and post-purchase evaluation.

Most of the previous studies analyzed the influence of the marketing mix on purchasing decisions and the influence of brand equity on purchasing decisions, while this study aimed to analyze the factors that influence purchasing decisions by including brand equity as intervening variables.

At first, rice was a commodity that did not rely on certain brands and marketing strategies to sell it. Rice is a basic necessity that should be easy to market, but due to the shifting consumer preferences towards rice products and the increasing level of competition between rice producers so that each producer strives to offer more uniqueness and value by providing packaging and brands for rice products, as well as conducting various marketing strategies to attract consumers. To save costs and time, rice producers must be able to develop marketing strategies and brand strategies that are most appropriate, effective, and efficient in marketing packaged rice products. In connection with the phenomenon, the authors intend to conduct research on marketing mix factors that affect brand equity and purchasing decisions of packaged rice products, as well as the influence of brand equity on the purchase decisions of packaged rice products. In this study, the factors that will be analyzed are the dimensions of the marketing mix, namely products, prices, locations, and promotions, as well as brand equity factors. The results of this study are expected to help Perum BULOG in particular, as well as rice producers in general, to formulate the strategy in order to increase consumer interest and encourage consumer to make the purchase decisions toward their packaged rice products.

\section{METHODS}

This study was conducted on 270 respondents living in DKI Jakarta and Bodetabek areas in September October 2020. The research location was chosen with the consideration that the market share for packaged rice products is mostly in large city areas. The design of this study uses a descriptive approach through survey methods by disseminating online questionnaires through the WhatsApp application. Sampling is based on the rule of thumb theory that the number of samples needed for each estimate of exogenous and endogenous variable parameters is five to ten observations (Hair et al. 2007). In relation to the number of indicator variables in this study amounted to 36 , then the minimum number for the research sample was 180 people. To deal with the possibility of sample data that can not be calculated, the sample that will be taken in this study is as much as $150 \%$ of the 180 that is 270 respondents.

In this study, the population was rice consumers in DKI Jakarta and Bodetabek. While the sampling unit is rice consumers that comes from the author's WhatsApp contacts and members of the author's WhatsApp group. Sampling techniques using non-probability sampling method through convenience sampling technique. With this method, samples are selected based on certain criteria in order to represent the population by screening at the beginning of the questionnaire filling. The criteria set out in this study are: 1) Respondents are decision-making in the process of purchasing rice, and 2) Respondents are consumers of packaged rice products. 
This research consists of dependent and independent variables as well as intervening variables. The independent variable are product, price, place, and promotion. The dependent variable is purchasing decisions. While the intervening variable is brand equity. The summary of operational variables can be seen in Table 1.

The measurement scale for each variable in the questionnaires uses an ordinal scale in the form of a Likert scale. The scale uses five attitude options where each option describes the level or degree that best suits the respondent. The five levels are; 1) strongly disagree, 2) disagree, 3) neutral, 4) agree, 5) strongly agree.

The purpose of this study is to analyze marketing mix factors namely product, price, place, and promotion that affect the brand equity of packaged rice products and the effect of product, price, place, promotion and brand equity on the purchase decisions of packaged rice products, as well as the indirect effect of product, price, place, and promotion on purchase decisions through brand equity. Based on the research framework in Figure 1, the hypothesis will be used as follows:
H1 : Product affect significantly on brand equity

H2 : Price affect significantly on brand equity

H3 : Place affect significantly on brand equity

H4 : Promotion affect significantly on brand equity

H5 : Product affect significantly on purchase decisions

H6 : Price affect significantly on purchase decisions

H7 : Place affect significantly on purchase decisions

H8 : Promotion affect significantly on purchase decisions

H9 : Brand equity affect significantly on Purchasing decisions

H10 : Product affect significantly on the purchase decisions through brand equity

H11 : Price affect significantly on the purchase decisions through brand equity

H12 : Place affect significantly on the purchase decisions through brand equity

H13 : Promotion affect significantly on the purchase decisions through brand equity

Table 1. Operational variables

\begin{tabular}{|c|c|c|c|}
\hline Variable & Definition & Indicator & References \\
\hline Product & $\begin{array}{l}\text { Everything that can be offered to the market in } \\
\text { order to attract attention, acquisition, use, or } \\
\text { consumption can satisfy a desire or need. }\end{array}$ & $\begin{array}{l}\text { Type; Design; Content; Taste; } \\
\text { Color; Grains. }\end{array}$ & Supriatna et al. (2017) \\
\hline Price & $\begin{array}{l}\text { A certain amount of money is needed to obtain a } \\
\text { combination of goods or services. }\end{array}$ & $\begin{array}{l}\text { Purchasing Ability; Quality; } \\
\text { Cheap. }\end{array}$ & Rahmah et al. (2018) \\
\hline Place & $\begin{array}{l}\text { The company's activities in providing goods and } \\
\text { services at the right time and place. }\end{array}$ & $\begin{array}{l}\text { Distance; Mini Mart; Market; } \\
\text { Supermarket; E-Commerce, }\end{array}$ & $\begin{array}{l}\text { Rahmah et al. (2018); } \\
\text { Supriatna et al. (2017) }\end{array}$ \\
\hline Promotion & $\begin{array}{l}\text { How manufacturers can communicate with } \\
\text { consumers so that consumers can know a product } \\
\text { or be aware of the existence of a product }\end{array}$ & $\begin{array}{l}\text { Electronic Ads; Print Ads; } \\
\text { Internet; SPG; Public Services. }\end{array}$ & $\begin{array}{l}\text { Windusara and Kusuma } \\
\text { (2015) }\end{array}$ \\
\hline $\begin{array}{l}\text { Brand } \\
\text { equity }\end{array}$ & $\begin{array}{l}\text { A set of assets and liabilities related to a brand, } \\
\text { name, and symbol that may add or decrease the } \\
\text { value provided by goods or services, namely brand } \\
\text { awareness, brand association, perceived quality, } \\
\text { and brand loyalty. }\end{array}$ & $\begin{array}{l}\text { Logo; Brands; Famous; } \\
\text { Local; Healthy; Famous } \\
\text { Company; Good Quality; } \\
\text { Good Reputation; Excellence; } \\
\text { Safety; Repeat Purchase; } \\
\text { Recommend; Loyalty. }\end{array}$ & $\begin{array}{l}\text { Nursaman et al. (2014); } \\
\text { Rahmah et al. (2018); } \\
\text { Chang and Liu (2009) }\end{array}$ \\
\hline $\begin{array}{l}\text { Purchase } \\
\text { decisions }\end{array}$ & $\begin{array}{l}\text { Consumer decisions in determining the choice of } \\
\text { products and services to be purchased. }\end{array}$ & $\begin{array}{l}\text { Brand Consideration; } \\
\text { Quality Consideration; } \\
\text { Price Consideration; Place } \\
\text { Consideration. }\end{array}$ & Tjiptono (2018) \\
\hline
\end{tabular}




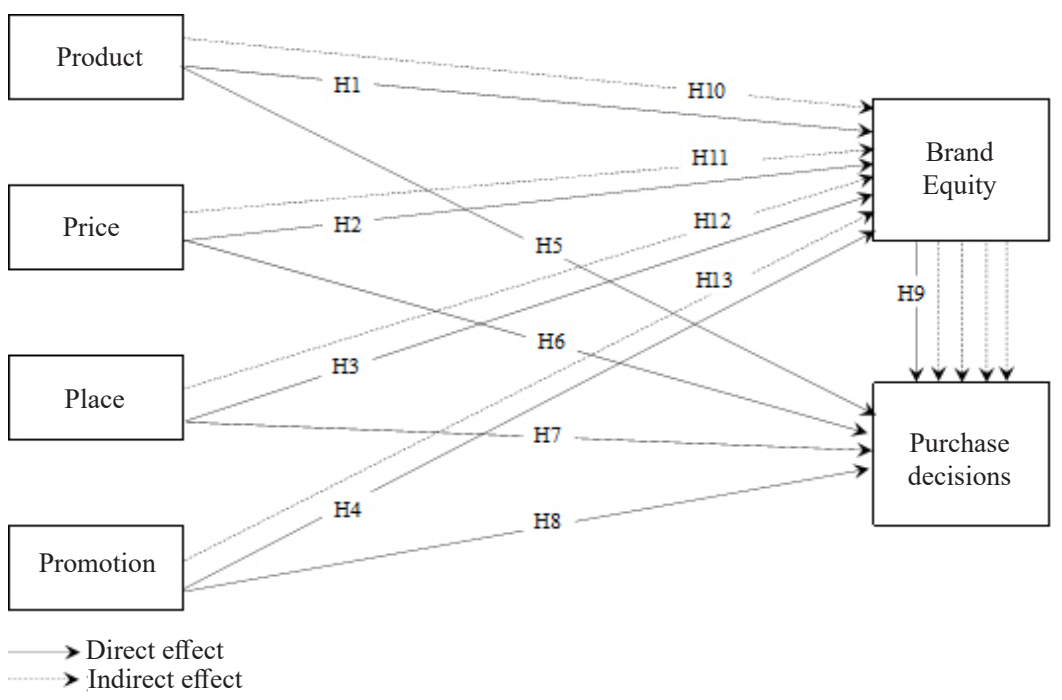

Figure 1. Research framework

This study uses descriptive analysis and Structural Equation Modelling (SEM) analysis to process and analyze data. The reason for using SEM compared to other methods is because the tool can perform three activities simultaneously, namely checking the validity and reliability of instruments which are functions of Confirmatory Factor Analysis (CFA), testing of relationship models between latent variables (path analysis), and obtaining useful models for forecasts (structural model functions or regression analysis). SEM is divided into 2 different methods, namely Covariance Based SEM (CB-SEM) and Variance Based SEM (VBSEM/PLS). In this study, researchers used CB-SEM method with Lisrel 8.80 software.

\section{RESULTS}

\section{Characteristics of Respondents}

The largest number of respondents was women at 62.2 percent with the dominant age of respondents in the $31-40$ age range of $39.9 \%$. The most education level of respondents is at the S1 level of $63 \%$, while the respondent job is mostly civil servants/state-owned enterprises by $43 \%$. Most respondent income is in the range of Rp5,000,000-Rp10,000,000 by $36.7 \%$. The group of respondents who spent money on food and beverage and for other needs were mostly in the same range, which is the range of $\mathrm{Rp} 1,000,000$ Rp2,000,000 with a percentage of $54.1 \%$ for food and beverage spending, and $31.1 \%$ for other needs. Married respondents dominated with a percentage of $77.8 \%$, while unmarried respondents were $20.7 \%$ and respondents who were widowed/widowers by $1.5 \%$. Meanwhile, most respondents had a family of 4, which is $28.9 \%$. Most of the respondents lived in East Jakarta with a total of $24.1 \%$ and the West Jakarta area of $19.3 \%$.

\section{Consumer Behavior}

For the most purchased rice brands, Topi Koki ranks first with a percentage of $34.8 \%$, while the most frequented place for consumers to buy packaged rice is supermarkets with a percentage of $41.9 \%$. Most of the respondents were as many as $57 \%$ of respondents answered the Market/Store as a source of information about the brand of rice. The majority of respondents (67.4\%) made rice purchases once a month and most of the respondents $(32.3 \%)$ stated that the last time they bought packaged rice was 1 week ago. The last purchase amount of packaged rice products made by respondents was $5 \mathrm{~kg}(37.8 \%)$. While the type of packaging purchased at the time of the last purchase of respondents is mostly $5 \mathrm{~kg}$ packaging with a percentage of $41.9 \%$. The price per $\mathrm{kg}$ of rice last purchased by respondents was mostly in the range of Rp12,001Rp13,000 with a percentage of $22.6 \%$. The most concern of respondents when buying rice is "Quality" which is with a percentage of $22.2 \%$.

\section{Validity and Reliability Test}

To test the validity of a construct, a loading factor value is used. An indicator is meet the criteria if the value of loading factor $(\lambda)>0.5$ (rule of thumb-Hair et al. 2007). Validity test results show that all indicators on 
latent variables have a loading factor value $(\lambda)>0.5$ with values ranging from 0.55 to 0.88 . Thus it can be stated that all indicators are good or valid and are of a significant nature to measure each latent variable of the product, price, location, promotion, brand equity, and purchase decision.

After the validity test, a reliability test is then conducted by calculating the Composite Reliability value to test the reliability value of the indicators on a variable. According to Ghozali \& Fuad (2008), a variable can be declared to meet composite reliability if the composite reliability value $>0.6$. In addition, the average variant extracted (AVE) value for each variable should be $>0.5$ for a good model. Reliability test results showed that the composite reliability value for all research variables $>$ 0.6 with values ranging from 0.76 to 0.93 . Additionally, it is known that the AVE value on all variables $>0.5$ with values ranging from 0.51 to 0.68 . Thus it can be stated that the whole variable has a good level of reliability.

\section{Goodness of Fit Test}

Based on the results of testing and matching the estimated value of Goodness of Fit (GOF), in Table 2 it can be seen that the value of Chi-Square does not fit, but the value of RMSEA, NFI, CFI, and RMR produces a good value or good fit so it can be concluded that the overall fit of this research model is a good fit.

\section{Analysis of Factors Influencing Brand Equity and Purchasing Decisions based on SEM Analysis}

In this study, the hypothesis was tested using Structural Equation Modeling (SEM) analysis. The structural results of the measurement model at the valuation stage of the model can be seen in Figure 2 with the value of loading factor and Figure 3 with the value of T-Values. Based on the results of SEM analysis, an overview of the indicators that give the largest contribution to each variable can be seen in Table 3.

Table 2. Goodness of fit test

\begin{tabular}{lccc}
\hline GOF & Accepted Value & Test Results & Conclusion \\
\hline Chi-Square & $\mathrm{P}>0.05$ & $\mathrm{P}=0.00$ & Does not fit \\
RMSEA & $\leq 0.08$ & 0.032 & Good Fit \\
NFI & $>0.90$ & 0.97 & Good Fit \\
CFI & $>0.90$ & 0.99 & Good Fit \\
RMR & $\leq 0.05$ & 0.049 & Good Fit \\
\hline
\end{tabular}

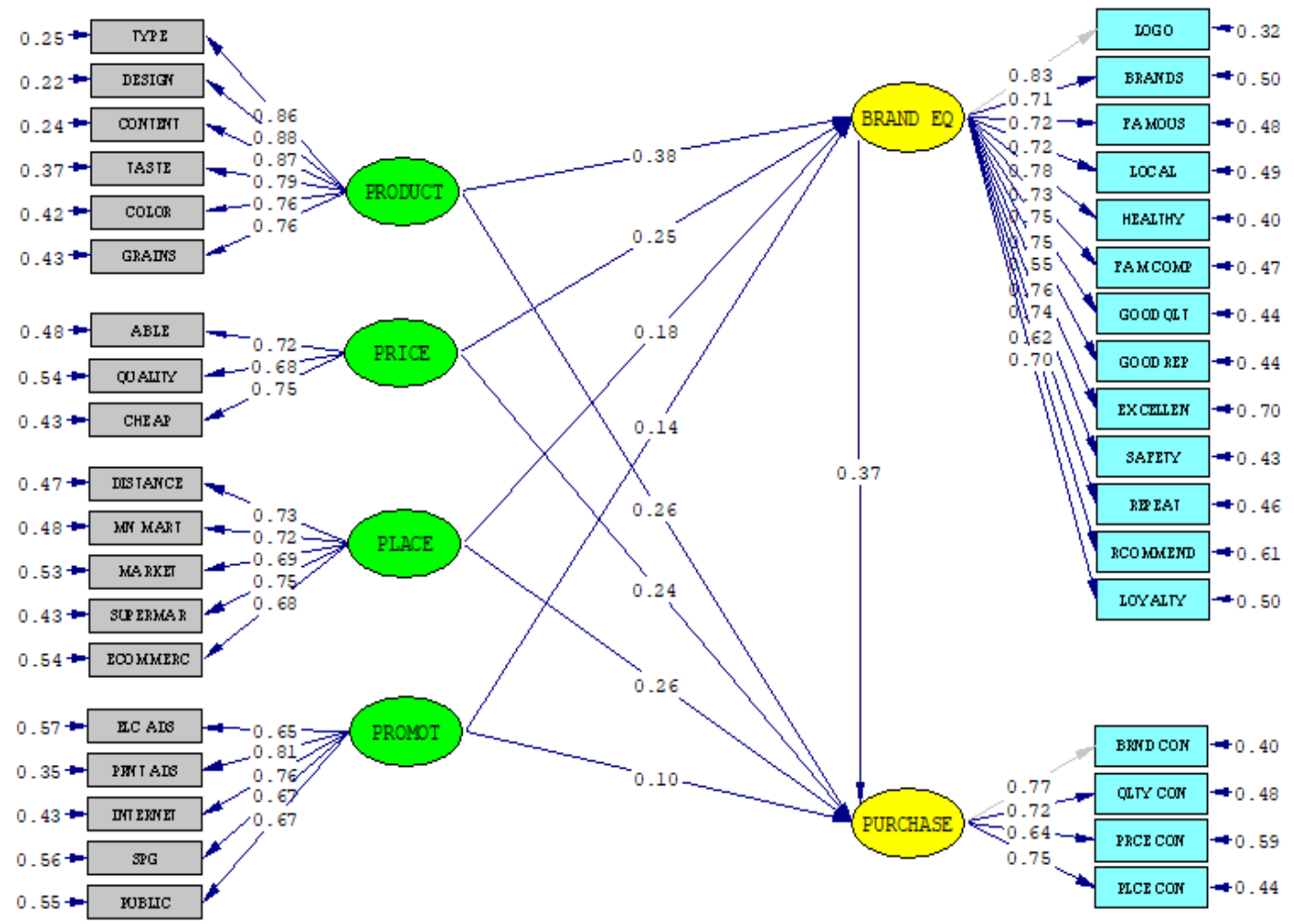

Figure 2. Path diagram based on standartdized solution (loading factor value) 


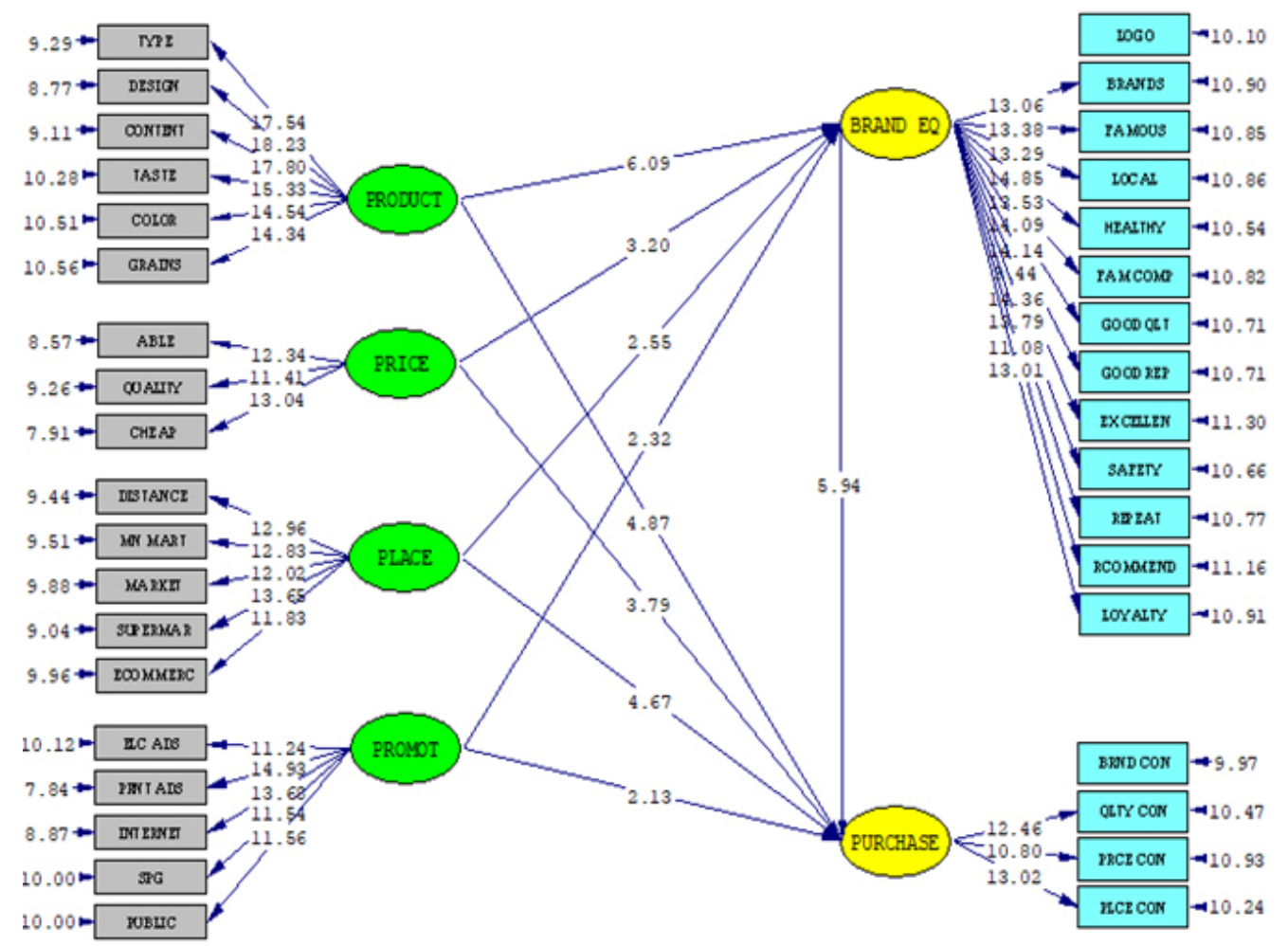

Figure 3. Path Diagram based on T-Values

Table 3. Indicators that contribute the most to each variable

\begin{tabular}{llcc}
\hline Variable & Indicators that contribute the most & Symbol & Loading Value \\
\hline Product & Attractive name and packaging design & $\mathrm{P} 2$ & 0.88 \\
Price & Rice prices are relatively cheaper than other rice products & $\mathrm{H} 3$ & 0.75 \\
Place & Avaliable in supermarkets frequently visited & $\mathrm{L} 4$ & 0.75 \\
Promotion & Printed media ads & $\mathrm{Pr} 2$ & 0.81 \\
Brand Equity & Identify the logo of a purchased rice brand & $\mathrm{EM} 1$ & 0.83 \\
\hline
\end{tabular}

Table 3 shows the indicators that contribute the most to each latent variable. Based on these results, it can be concluded that the name and design of packaged rice products are the main factors that consumers consider most when buying rice. While in terms of price, consumers tend to choose the product at a cheaper price than other products. Then in terms of the location of purchase, consumers will choose and buy packaged rice products contained in supermarkets and/or supermarkets that they often visit to shop. Promotional media for packaged rice products that are most viewed by consumers are advertisements in print media such as magazines, newspapers, pamphlets, brochures, and others. Furthermore, when it comes to brand equity, the logo of packaged rice product is very important in representing a brand of rice.

\section{Hypothesis Verification Results}

Table 4 shows that based on the hypothetical test results on each path all resulted in T-values greater than the T-table (1.968), thus the H0 hypothesis was rejected and $\mathrm{H} 1$ accepted, meaning that product, price, place, and promotion had a significant positive effect on brand equity and purchase decisions.

The first hypothesis results show that the coefficient of path value was 0.38 with a calculated T value (6.09) $>\mathrm{T}$ table (1.968). Based on these results, it can be concluded that the first hypothesis is accepted. The significant positive effect of the product on brand equity explains that the higher the value of name and packaging design, the brand equity of packaged rice products will also be higher or increased. This is aligned with Yoo et al. (2000) and Aghaei et al. (2014) that there was a positive and meaningful relationship between the marketing mix and brand equity. 
Table 4. Results of direct effect hypothesis test

\begin{tabular}{lccc}
\hline Path & Coefficient & T values & Conclusion \\
\hline Product $\rightarrow$ Brand Equity & 0.38 & 6.09 & Significant Effect \\
Price $\rightarrow$ Brand Equity & 0.25 & 3.20 & Significant Effect \\
Place $\rightarrow$ Brand Equity & 0.18 & 2.55 & Significant Effect \\
Promotion $\rightarrow$ Brand Equity & 0.14 & 2.32 & Significant Effect \\
Product $\rightarrow$ Purchase Decisions & 0.26 & 4.87 & Significant Effect \\
Price $\rightarrow$ Purchase Decisions & 0.24 & 3.79 & Significant Effect \\
Place $\rightarrow$ Purchase Decisions & 0.26 & 4.67 & Significant Effect \\
Promotion $\rightarrow$ Purchase Decisions & 0.10 & 2.13 & Significant Effect \\
Brand Equity $\rightarrow$ Purchase Decisions & 0.37 & 5.94 & Significant Effect \\
\hline
\end{tabular}

The second hypothesis results show that the coefficient of path value was 0.25 with a calculated $\mathrm{T}$ value (3.20) $>\mathrm{T}$ table (1.968). Based on these results, it can be concluded that the second hypothesis is accepted. The significant positive effect of price on brand equity explains that the lower the price of rice compared to the competitor's price, the brand equity of packaged rice products will also be higher or increased. This is aligned with Taboli et al. (2017) who shows that price affects brand equity through quality perception.

The third hypothesis results show that the coefficient of path value was 0.18 with a calculated $\mathrm{T}$ value (2.55) $>\mathrm{T}$ table (1.968). Based on these results, it can be concluded that the third hypothesis is accepted. The significant positive effect of place on brand equity explains that the more distribution of packaged rice products to supermarkets, the brand equity of packaged rice products will also be higher or increased. This is aligned with Taboli et al. (2017) who also shows that place or distribution channels affect brand equity through quality perception.

The fourth hypothesis results show that the coefficient of path value was 0,14 with a calculated $\mathrm{T}$ value (2.32) $>$ T table (1.968). Based on these results, it can be concluded that the fourth hypothesis is accepted. The significant positive effect of promotion on brand equity explains that the more often rice producers place advertisements in print, the higher the brand equity of packaged rice products. This is aligned with Haidi and Wandebori (2016) that a manufacturer should further develop promotional activities to increase Brand Awareness in Brand Equity.

The fifth hypothesis results show that the coefficient of path value was 0.26 with a calculated $\mathrm{T}$ value (4.87) $>\mathrm{T}$ table (1.968). Based on these results, it can be concluded that the fifth hypothesis is accepted. The significant positive effect of product on purchase decision explains that the higher the value of the name and packaging design, the higher the consumer's desire in making purchase decisions. This is aligned with Marwa et al. (2014) that the product mix is the variable that most influences life insurance purchasing decisions.

The sixth hypothesis results show that the coefficient of path value was 0,24 with a calculated $\mathrm{T}$ value (3.79) $>\mathrm{T}$ table (1.968). Based on these results, it can be concluded that the sixth hypothesis is accepted. The significant positive effect of price on purchase decisions explains that the lower the price of rice compared to the competitor's price, the higher the consumer's desire in making purchase decisions. This is aligned with Aritonang et al. (2015) that variable of prices has a significant influence on the purchasing decisions of soybean meal raw materials.

The seventh hypothesis results show that the coefficient of path value was 0.26 with a calculated $\mathrm{T}$ value (4.67) $>\mathrm{T}$ table (1.968). Based on these results, it can be concluded that the seventh hypothesis is accepted. The significant positive effect of place on purchase decisions explains that the more distribution of packaged rice products to supermarkets, the higher the consumer's desire in making purchase decisions. This is aligned with Aritonang et al. (2015) that place has a significant influence on the purchasing decisions.

The eighth hypothesis results show that the coefficient of path value was 0.10 with a calculated T value (2.13) $>\mathrm{T}$ table (1.968). Based on these results, it can be concluded that the eighth hypothesis is accepted. The significant positive effect of promotion on purchase decisions explains that the more often rice producers place advertisements in print, the higher the consumer's 
desire in making purchase decisions. This is aligned with Hia (2012) that there is a significant influence between promotion on consumer decisions to buy Sari Murni cooking oil.

The ninth hypothesis results show that the coefficient of path value was 0.37 with a calculated $\mathrm{T}$ value (5.94) $>\mathrm{T}$ table (1.968). Based on these results, it can be concluded that the ninth hypothesis is accepted. The significant positive effect of brand equity on purchase decisions explains that the easier the logo of rice brand can be recognized, the higher the consumer's desire in making purchase decisions. This is aligned with Meiria (2017), Akhtar et al. (2016), and Randang (2013), who showed that brand equity factors have a significant effect on purchasing decisions.

Table 5 shows that based on the hypothetical test results on each path all resulted in T-values greater than the T-table (1.968), thus the H0 hypothesis was rejected and $\mathrm{H} 1$ accepted, meaning that product, price, place, and promotion had a significant indirect effect on purchasing decisions through brand equity as intervening variables. Furthermore, in Table 6 it can be seen that the total effect is greater than the direct effect, this concludes that in addition to the marketing mix strategy, producers and marketers must apply branding and packaging strategies well in order to improve consumer purchasing decisions on their rice products.

Based on the results of the SEM analysis, it is known that the R-Square value for the brand equity is 0.55 . This explains that the percentage of product, price, place, and promotion can explain brand equity is $55 \%$. While the remaining $45 \%$ is influenced by other factors outside this model. Then for the R-Square value for the purchase decision is 0.94 . The value explains that the percentage of product, price, place, promotion and brand equity can simultaneously explain the purchase decision is $94 \%$. While the remaining $6 \%$ is influenced by other factors besides product, price, place, promotion, and brand equity such as motivation, lifestyle, perception, and residential environment.

\section{Managerial Implications}

Based on SEM analysis that has been done, product, price, place, and promotion, have a significant influence on brand equity and purchasing decisions of packaged rice products. In connection with this, by referring to the greatest contribution to each variable, the managerial implications that can be given to rice producers to develop and implement marketing mix strategies and brand strategies are as follows.

The indicators that contribute the most to the product are the attractive name and packaging design. The manufacturers should increase their budget and focus their entire resources on brand development and packaging design so that their rice products can be more competitive in the market.

The indicator that contributes the most to the price is the price of rice is relatively cheaper than other rice products. In implementing a pricing strategy, to maintain that the price remains cheaper than the price of competitors, producers must be able to reduce production costs and other costs without lowering the quality. For example, manufacturers can reduce the cost of raw materials by looking for grain suppliers that offer lower prices of the same quality.

Table 5. Results of indirect effect hypothesis test

\begin{tabular}{lccc}
\hline Path & Coefficient & T values & Conclusion \\
\hline Product $\rightarrow$ Brand Equity $\rightarrow$ Purchase Decisions & 0.14 & 4.30 & Significant Effect \\
Price $\rightarrow$ Brand Equity $\rightarrow$ Purchase Decisions & 0.09 & 2.96 & Significant Effect \\
Place $\rightarrow$ Brand Equity $\rightarrow$ Purchase Decisions & 0.06 & 2.39 & Significant Effect \\
Promotion $\rightarrow$ Brand Equity $\rightarrow$ Purchase Decisions & 0.05 & 2.16 & Significant Effect \\
\hline
\end{tabular}

Table 6. Coefficient of direct effect, indirect effect, and total effect

\begin{tabular}{lccccc}
\hline Path & Direct Effect & Indirect Effect & Total Effect & T values & Conclusion \\
\hline Product $\rightarrow$ Purchase Decisions & 0.26 & 0.14 & 0.40 & 7.07 & Significant Effect \\
Price $\rightarrow$ Purchase Decisions & 0.24 & 0.09 & 0.33 & 4.84 & Significant Effect \\
Place $\rightarrow$ Purchase Decisions & 0.26 & 0.06 & 0.32 & 5.26 & Significant Effect \\
Promotion $\rightarrow$ Purchase Decisions & 0.10 & 0.05 & 0.15 & 2.90 & Significant Effect \\
\hline
\end{tabular}


The indicators that contribute the most to the place is that it is located in supermarkets that are frequently visited. The producers of packaged rice should develop a distribution channel strategy that focuses on supermarkets and supermarkets.

The indicators that contribute the most to promotion are advertisements in print (magazines, newspapers, etc.). Therefore, rice producers should prioritize print media such as magazines, newspapers, pamphlets, brochures and so on to advertise.

The indicator that contributes the most to brand equity is recognizing the logo of brands. In order to increase brand awareness, rice producers must be able to create attractive, unique, memorable, and different logo designs than competitors so that consumers can directly recognize a particular brand of rice just by looking at the logo of the brand. Brand awareness is very important to instil in the minds of consumers. With high brand awareness, consumers will have no trouble finding the brand of rice they want to buy when faced with a wide selection of rice brands.

Based on the results of the hypothesis test, the variable that has the most influence on brand equity is the product. While variable that most influences purchase decisions is the product, place, and brand equity. In connection with this, it can be concluded that product, place, and brand equity are factors of the marketing mix that should be a top priority for producers and marketers of rice to be improved and developed.

\section{CONCLUSIONS AND RECOMMENDATIONS}

\section{Conclusions}

Based on the results of the study, consumer perception of marketing strategy and brand strategy of packaged rice products is that in deciding to buy packaged rice, the things that consumers consider from the product factor itself is the name and design of the packaging, from the price factor is a relatively cheaper price compared to other rice products, from the place factor is the packaged rice product is found in supermarkets that they often visit, from the promotion factor is the presence of advertisements in print, and from the brand equity factor is a brand logo that is easily recognized.
Based on the results of hypothetical tests, product, price, place, and promotion have a significant positive influence on brand equity. The variable that has the most influence on brand equity is the product variable. In connection with this, product is a variable that should be a top priority for manufacturers and marketers to be improved and developed. This is to strengthen the brand equity of packaged rice products.

Based on the results of hypothetical tests, product, price, place, promotion, and brand equity have a significant positive influence on purchase decisions. The variables that have the most influence on purchase decisions are product, place, and brand equity. In connection with this, it can be concluded that to improve the decision to purchase packaged rice products; products, place, and brand equity are variables that should be a top priority for manufacturers and marketers to be improved and developed.

Based on the results of hypothetical tests, product, price, place, and promotion have a significant indirect effect on purchase decisions through brand equity as intervening variables. The result of the total effect is greater than direct effect concludes that in addition to the marketing mix strategy, manufacturers and marketers must implement brand and packaging strategies well in order to improve consumer purchase decisions on their rice products. Based on the results of this study can also be concluded that rice products sold using brands and packaging will attract more consumer interest than bulk rice products sold without brands and packaging. There are 3 (three) strategies that can be applied in order to increase sales of packaged rice products, the first is to increase the budget and allocation of human resources to develop the brand and packaging design of rice products in order to attract more consumers. The second strategy is to choose distribution channels that focus on supermarkets to make it easier and faster for consumers to find the rice products they want to buy at the sales locations they frequent. The third strategy is to create a logo design that is attractive, unique, memorable, and different from competitors so that consumers can immediately recognize a particular brand of rice just by looking at the logo of the rice brand. 


\section{Recommendations}

Based on the value of The Determination Coefficient $\left(\mathrm{R}^{2}\right)$, the variable percentage of product, price, place, promotion, and brand equity can simultaneously explain the purchase decision is $94 \%$. While the remaining $6 \%$ is influenced by other factors outside this model. In connection with this, for further research, it can be added other variables that might affect purchasing decisions, such as motivation, lifestyle, perception, and residential environment.

This study was conducted on consumer of rice products in general. For further research, it is recommended that the research focus on consumers of certain brand rice products so that the results of the research can be used specifically by the producers of the rice brands studied.

Because this research was conducted during the Covid19 pandemic, there are limitations in the dissemination of questionnaires that are only conducted through online media, namely the WhatsApp application. For further research, it is suggested that it can also be done offline by disseminating questionnaires in various rice sales locations such as traditional markets, supermarkets, mini markets, grocery stores and others so that the data source can cover a wider demographic of respondents.

\section{REFERENCES}

Aaker DA. 1997. Managing brand equity: capitalizing on the value of a brand name. New York: Free Press.

Adelina N. 2016. Pengaruh brand equity terhadap keputusan pembelian minuman isotonik mizone di Bandung. Image: Jurnal Riset Manajemen 3(1):1-10.

Adebisi Y. 2006. Essential of marketing management. Lagos: Cilgal Publication.

Aghaei M, Vahedi E, Kahreh MS, Pirooz M. 2014. An examination of the relationship between services marketing mix and brand equity dimensions. Procedia-Social and Behavioral Sciences 109:865-869. https://doi.org/10.1016/j. sbspro.2013.12.555

Akhtar N, Siddiqi UI, Ashraf A, Latif M. 2016. Impact of a brand equity on consumer purchase decision in L'Oreal Skincare products. International Review of Management and Business Research,
5(3):808.

Aritonang PA, Daryanto A, Hendrawan DS. 2015. Analisis pengaruh bauran pemasaran terhadap keputusan pembelian bahan baku bungkil kedelai pada industri pakan ternak di Indonesia. Jurnal Aplikasi Manajemen 13(3):474-482.

Chandra IR. 2015. The Impact of Marketing Mix Elements toward Brand Equity through Brand Awareness and Brand Image as Mediators in Bakery Industry in Indonesia. iBuss Management 3(2):341-350.

Chang HH, Liu YM. 2009. The impact of brand equity on brand preference and purchase intentions in the service industries. The Service Industries Journal 29: 1687-1706. https://doi. org/10.1080/02642060902793557

Etriya, Sumarwan, Kirbrandoko. 2004. Analisis ekuitas berbagai merek minyak goreng. Jurnal Manajemen dan Agribisnis 1(2): 127-139.

Ghozali I, Fuad. 2008. Structural equation modeling: Teori, konsep, dan aplikasidengan program Lisrel 8.80. Badan Penerbit Universitas Diponegoro.

Haidi MF, Wandebori H. 2016. Determining brand equity and marketing mix in bakery store (case study: rogheef bakery). Journal of Business and Management 5(1): 154-168.

Hair JF, Anderson RE, Tatham RL, Black WC. 2007. Multivariate Data Analysis (6 ed.). New Jersey: Pearson Education Prentice Hall, Inc.

Hia YD, 2012. Pengaruh bauran pemasaran terhadap keputusan pembelian minyak goreng sari murni. Journal of Economic and Economic Education 1(1):97-102.

Kotler P, Keller, K. 2006. Marketing management (12 th edition). NY: Prentice-Hall.

Marwa S, Sumarwan, U, Nurmalina, R, 2014. Bauran pemasaran memengaruhi keputusan konsumen dalam pembelian asuransi jiwa individu. Jurnal Ilmu Keluarga dan Konsumen 7:183-192. https:// doi.org/10.24156/jikk.2014.7.3.183

Meiria E, 2017. Ekuitas merek dan keputusan pembelian: studi pada konsumen anak usia sekolah dasar di Kota Depok. Esensi 7:111-130. https://doi.org/10.15408/ess.v7i1.4783

Nursaman E, Sumarwan U, Djohar S. 2014. Ekuitas merek jasa gerai buah-buahan berdasarkan persepsi konsumen. Jurnal Manajemen dan Agribisnis 11(2):89-99.

Nugroho T, Sumarwan U, Kirbrandoko K. 2015. Factors influencing the purchase decision of organic tofu. Indonesian Journal of Business 
and Entrepreneurship 1(3):115-126. https://doi. org/10.17358/IJBE.1.3.115

Rahmah K, Sumarwan U, Najib M. 2018. The effect of brand equity, marketing mix, and lifestyle toward purchase decision at coffee shop in Bogor. Journal of Consumen Sciences 3(2):1-15.

Randang W, 2013. Kualitas produk, atribut produk Dan ekuitas merek pengaruhnya terhadap keputusan pembelian minyak goreng. Jurnal EMBA 1(3): 701-709.

Sumarwan U, Noviandi A, Kirbrandoko. 2013. An analysis of purchasing decision, perceptions and consumer attitudes toward organic rice in Jabodetabek. Pangan 22(2):87-103.

Supriatna D, Nurrochmat DR, Fahmi I. 2017. Pengaruh bauran pemasaran, ekuitas merek terhadap keputusan pembelian benih cap kapal terbang di Jawa Barat. Jurnal Aplikasi Bisnis Dan Manajemen (JABM) 3(3): 341-252. https://doi. org/10.17358/jabm.3.3.341
Sutrisno S. 2007. Trend pemasaran beras di Indonesia. Jurnal Pangan 16(1):10-22.

Taboli H, Pariz N, Vafada M. 2017. Assessing the impact of marketing mix on brand equity. International Journal of Scientific Study 5(4):612-621. https:// doi.org/10.17354/ijssI/2017/85

Tjiptono F. 2018. Pemasaran strategik. 4th ed. Yogyakarta: Andi publisher.

Ulfah I, Sumarwan U, Nurrochmat DR. 2016. Marketing mix factors that influence the desire to purchase fruit beverages in the city of Bogor. Indonesian Journal of Bussiness and Enterpreneurship 2(1). https://doi.org/10.17358/ijbe.2.1.33

Windusara DBN, Kusuma AA.2015. Pengaruh bauran promosi terhadap keputusan pembelian Oppo Smartphone. E-Jurnal Manajemen Universitas Udayana 4(12): 4160-4185.

Yoo B, Donthu N, Lee S. 2000. An examination of selected marketing mix elements and brand equity. Journal of the Academy of Marketing Science 28: 195-211. https://doi. org/10.1177/0092070300282002 